\title{
Ornamental rare grasses in the North-Eastern part of Azerbaijan
}

\section{Parvin N. Aghayeva \\ Institute of Botany, Azerbaijan National Academy of Sciences, Badamdar 40, Baku, AZ1004, Azerbaijan}

Abstract: The article deals with wild species of rare ornamental herbs growing in Quba and Qusar districts of Azerbaijan, south-eastern part of Greater Caucasus. During 2013-2019 years in total, about 500 specimens were collected and identified as 235 taxa based on the main diagnostic morphological characters. Of those 21 taxa belonging to 18 genera were rare plants included in the second edition of the Red Book of Azerbaijan. Considering the latest taxonomic and nomenclatural changes these include Alcea kusariensis, Asrtagalus kubensis, Crocus biflorus subsp. adamii, C. speciosus, Epipactis palustris, Galanthus alpinus, Himantoglossum formosum, Iris caucasica, Limodorum abortivum, Muscari armeniacum, Ophry sapifera, O. sphegodes subsp. mammosa, Orchis purpurea, Planthera chlorantha, Phelypaea coccinea, Primula algida, Primula heterochroma, Pulsatilla albana, Scilla siberica subsp. caucasica, Tanacetum coccineum and Tulipa biebersteiniana belonging to the five orders, seven families. Species have been recorded in more than one altitude zone. Most of rare species occur in low and middle mountain zones. Few species are recorded in higher elevations. Life forms and flowering period of plants were also investigated. Cephalanthera damasonium, C. longifolia, Fritillaria lutea and Muscari armeniacum are new rare plants that need protection of which insertion to the third edition of the Red Book of Azerbaijan is proposed.

Key Words: Greater Caucasus, diversity, herb plants, life forms, Red Book

\section{INTRODUCTION}

Biodiversity is threatened worldwide. Total number of land plant species are around 500.000 and many species are still unknown to science and significant parts of these plants are under risk. About $40 \%$ of global flora considered rare or under risk due to the increase of global pollution and climate change [Enquist et al.,

Accepted for publication: 8 May 2020

E-mail: apn_aghayeva@yahoo.com
2019]. Negative influence of human activity is widely recognized, and it demands the international action on plant conservation [Corlett, 2016; Knapp, 2011]. Plants are the foundation in all terrestrial ecosystems. Food, health and energy security greatly depends on plants. Life in the rural areas based on many more on plants. Thus conservation of all plant species is expediently for range of reasons, including aesthetic, scientific and ethical grounds [Corlett, 2016].

Some species are estimated as rare or threatened, but it is still unclear; those are rare due to the natural (inherent) features, dispersal capacity, or abiotic environmental condition. Important role of the environmental condition is in determining why some species are abundant and others are rare [Wamelink et al., 2014]. Habitat may have limited factors such as availability of nutrient, groundwater, soil $\mathrm{pH}$, existing vegetation structure etc. Habitat loss, fragmentation and degradation are among the major threats.

Species abundance and species occupancy across the local geographic range tend to be correlated and in this case rare species tend to also show up in only a few local communities [Enquist et al., 2019]. Estimation of rarity in global scale can therefore minimize the doubts concerning whether a species is rare. The role of the rare species is highly disputable. Rare species are important in maintainers of ecosystem, and this is widely investigated for supporting the most distinctive and vulnerable functions in the high diversity ecosystems [Mouillot et al., 2013]. They request more attention, because these are often being the first to disappear.

As it is well known, locally rare taxon is rare only in a given geographical boundary, but not outside that boundary. Identification of rare taxa locally is very important for recognition of their status and preservation. This information is also necessary for the identification of the rare taxa globally, nationally and provincial levels [Crain, White, 2011]. Development decision on the rarity of taxa happens first at local, then regional levels and conservation measures for protection of the species diversity still must be agreed in the national level.

The interest in ornamental plants was growing exponentially over the last decades. Continued reduction of natural resources necessitates using hardy ornamental plants with low maintenance requirements 
for creating urban landscapes, especially those plants displaying inherent tolerance to environmental stresses [Heywood, 2003; Gray, Brady, 2016].

Ornamental plants in Azerbaijan was little studied [Flora of Azerbaijan, 1950-1961; Tutayuk et al., 1961]. The study of the ornamental flora of Quba and Qusar districts was launched in 2013. The objective of the present study was to report the patterns of known and new rare ornamental herb species in Quba-Qusar districts of Azerbaijan.

\section{MATERIAL AND METHODS}

The Quba and Qusar are adjacent districts with territory respectively $1542 \mathrm{~km}^{2}$ and $2574 \mathrm{~km}^{2}$ located at 500-4466 $\mathrm{m}$ above sea level in the North-Eastern part of Azerbaijan which is considered one of the most naturally floristically rich area within the country. These two districts have been used as a recreational area for many years and vegetation has exposed to strong anthropressure, which requires continuous study of vegetation. Human impact, recreational activities are highly increased during last couple of decades due to the faster growing infrastructure and service sector, such as travel and tourism economy in the country.

Approximately 500 specimens were collected and 235 herbal taxa were recorded in the territory during 2013-2019 of which 25 were rare taxa. Plants for our analysis were chosen based on phonological and morphological features (structure of flowers, stem, leaves) and overall aesthetic qualities. Each collected sample was characterized based on morphology and identified visually or by using a dissection microscope [Sunshine ST-3024R-2L, China]. Identification of samples was implemented based on available literature on the local flora, and recent checklists [Flora of Azerbaijan, 1961; Caucasian flora conspectus, 2008, 2012; Alizade et al., 2019]. The species status was also checked following the "An Online Flora of All Known Plants" (www.worldfloraonline.org) and "The Plant List" (http://www.theplantlist.org). Plant life forms were determined according to C. Raunkiaer [1934] and I. Serebryakov [1964].

\section{RESULTS AND DISCUSSION}

Species diversity. The study area locates along various altitude belts that include foothills, low, middle and high mountain zones, subalpine and alpine habitats. Herbs growing here could be mainly related to the spring flora but there are also occur species blooming in summer and autumn [Aghayeva et al., 2018]. Altogether about
235 taxa of 28 orders, 44 families and 140 genera of ornamental plants were recorded in Quba and Qusar districts during our study. In this study we report 23 species and two subspecies belonging to four plant groups, eight orders, 11 families and 20 genera that are considered as rare for these districts (Table).

Monocots are prevailing in the number of species and include species of the orders Liliales and Asparagales. Liliales is represented with Fritillaria lutea Mill. which is unresolved name according to World Checklist of selected plant families (WCSP data supplied on 2012-03-23). Another species of this family is Tulipa biebersteiniana Schult. \& Schult. f.

The order Asparagales include taxa of the familes Orchidaceae, Iridaceae and Amaryllidaceae. The family Orchidaceae include Epipactis palustris, Himantoglossum formosum, Limodorum abortivum, Ophrys apifera, Ophrys sphegodes subsp. mammosa, Planthera chlorantha and Orchis purpurea. Two Ophrys species were mentioned as Ophrys oestrifera and Ophrys caucasica in the Red Book of Azerbaijan (2nd ed; 2013). The status of the species Orchis purpurea is ambiguous in the World Flora Online (WFO) but is accepted name in The Plant list.

Recorded rare irises were Crocus biflorus subsp. adamii (Syn.: Crocus adamii J. Gay), Crocus speciosus and Iris caucasica. One more species of this order was Galanthus alpinus Sosn. belonging to the amaryllis family (Amaryllidaceae).

Eudicots were represented with Pulsatilla albana of the Ranunculaceae family, order Ranunculales. Rosids and Asterids represented with two and three species respectively. Rosids includes Asrtagalus kubensis Grossh. (Fabaceae, Fabales) and Alcea kusariensis (Malvales, Malvaceae) of which the latter is mentioned as unresolved name in The Plant List and ambiguous in WFO. Asterids includes and Phelypaea coccinea (M. Bieb.) Poir., Tanacetum coccineum (Asteraceae, Asterales), Primula algida and P. heterochroma (Primulaceae, Ericales). In The Plant List $P$. heterochroma is recorded as unresolved name and it is also mentioned as ambigous in the WFO. Tanacetum coccineum is an accepted name with its original publication diagnosis in both data bases, but mentioned with low confidence level.

Above mentioned 20 taxa are given as rare and endangered in the last Red Book (2013) of the country, of those 11 species (55\%) mentioned as vulnerable (VU), five species $(25 \%)$ as endangered $(\mathrm{EN})$, three species $(15 \%)$ as near threatened (NT) and one species $(5 \%)$ 


\section{PLANT \& FUNGAL RESEARCH}

Table. Taxonomic structure of the rare grasses in the North-Eastern part of Azerbaijan.

\begin{tabular}{|c|c|c|c|}
\hline Order & Family & Species & $\begin{array}{l}\text { National level assessment as in } \\
\text { Red Book [2013] }\end{array}$ \\
\hline \multirow{2}{*}{ Liliales } & \multirow{2}{*}{ Liliaceae } & Fritillaria lutea Mill. & $*$ \\
\hline & & Tulipa biebersteiniana Schult. \& Schult. f. & $\mathrm{VU}, \mathrm{A} 2 \mathrm{c}+3 \mathrm{c}$ \\
\hline \multirow{15}{*}{ Asparagales } & & Muscari armeniacum Leichtlin ex Baker & $*$ \\
\hline & Asparagaceae & $\begin{array}{l}\text { Scilla siberica subsp. caucasica (Miscz.) } \\
\text { Mordak }\end{array}$ & NE, ENB2ab(i, ii, iii) \\
\hline & \multirow{9}{*}{ Orchidaceae } & Cephalanthera damasonium (Mill.) Druce & * \\
\hline & & Cephalanthera longifolia (L.) Fritsch & * \\
\hline & & Epipactis palustris (L.) Crantz & VU, B1ab (iii)+2ab(iii) \\
\hline & & Himantoglossum formosum (Steven) K. Koch & $\mathrm{EN}, \mathrm{A} 2 \mathrm{acd}+3 \mathrm{bc} ; \mathrm{C} 1$ \\
\hline & & Limodorum abortivum (L.) Sw. & VU, D2 \\
\hline & & $\begin{array}{l}\text { Ophrys apifera Huds. (Syn.: Ophrys oestrifera } \\
\text { M. Bieb.) }\end{array}$ & EN, B1ab(iii)+2ab(iii) \\
\hline & & $\begin{array}{l}\text { Ophrys sphegodes subsp. mammosa (Desf.) Soó } \\
\text { ex E. Nelson }\end{array}$ & VU, B1ab(iii,iv)+2ab(iii) \\
\hline & & Orchis purpurea Huds. & EN, B1 ab(i,iii,iv)+2ab(iv) \\
\hline & & Planthera chlorantha (Custer) Rchb. & VU, D2 \\
\hline & \multirow{3}{*}{ Iridaceae } & Crocus biflorus subsp. adamii (J.Gay) K.Richt. & VU, B1ab(iii,iv)+2ab(iii) \\
\hline & & Crocus speciosus Bieb. & VU, B1ab(iii,)+2ab(iii) \\
\hline & & Iris caucasica Hoffm. & NT \\
\hline & Amaryllidaceae & $\begin{array}{l}\text { Galanthus alpinus Sosn. (Syn.: Galantus } \\
\text { caucasicus (Baker) Grossh.) }\end{array}$ & $\begin{array}{l}\text { EN, } \\
\text { B1ab(i,ii,v)+c(i,ii,iii)+2ab(i)c(ii,v) }\end{array}$ \\
\hline Ranunculales & Ranunculaceae & Pulsatilla albana (Stev.) Bercht. \& J. Presl & NT \\
\hline Fabales & Fabaceae & Asrtagalus kubensis Grossh. & VU, D2 \\
\hline Malvales & Malvaceae & Alcea kusariensis Iljin ex Grossh & EN, B1ab(v)+B2ab(v) \\
\hline Lamiales & Orobanchaceae & $\begin{array}{l}\text { Phelypaea coccinea (M. Bieb.) Poir. (Syn.: } \\
\text { Diphelypaea coccinea (M. Bieb.) Nicolson) }\end{array}$ & NT \\
\hline Asterales & Asteraceae & Tanacetum coccineum (Willd.) Grierson & $\mathrm{VU}, \mathrm{A} 2 \mathrm{c}+3 \mathrm{c}$ \\
\hline \multirow{2}{*}{ Ericales } & \multirow{2}{*}{ Primulaceae } & Primula algida Adams & $\mathrm{VU}, \mathrm{A} 2 \mathrm{c}+3 \mathrm{c}$ \\
\hline & & Primula heterochroma Stapf. & VU, D2 \\
\hline
\end{tabular}

not evaluated (NE). Four more species, Cephalanthera damasonium (Mill.) Druce, C. longifolia, Fritillaria lutea and Muscari armeniacum were suggested as rare considering results of study during last five years in these two districts. Untill now Primula heterochroma was reported only from Lenkoran district of Azerbaijan [Flora of Azerbaijan, 1957]. The species was also found in Quba district during the field surveys in 2013 and in Qusar district in 2017 (Fig.).

Plant life forms. Various life forms appear in the ontogenesis of plants, depending on the characteristics of inheritance and the ecological condition, which leave prints as morphogenetic changes. Life forms reflect and partly determine the functions of plants in ecosystems. As it is well known, systematically closely related species may have different life forms. Elevation and ecological factors, such as the type of soil, light, temperature, and humidity affects the life forms of plants and they grow as annual, biennial or perennial.

Many species occur in both forests and grasslands. Some of them grow along mountain slopes, and also occur in meadows. Morphological features, especially root system of plants is very variable and better adopted to the living environment conditions. Of reported species some have rhizomes from which new roots and stems grow each year. These include E. palustris, $H$. formosum, L. abortivum. The rhizome of E. palustris is small up to $1 \mathrm{~cm}$ thick. In this species rhisome is alwayse associated with fungi. The species occurs in mixed forests and prefers humid grasslands and woodlands. 

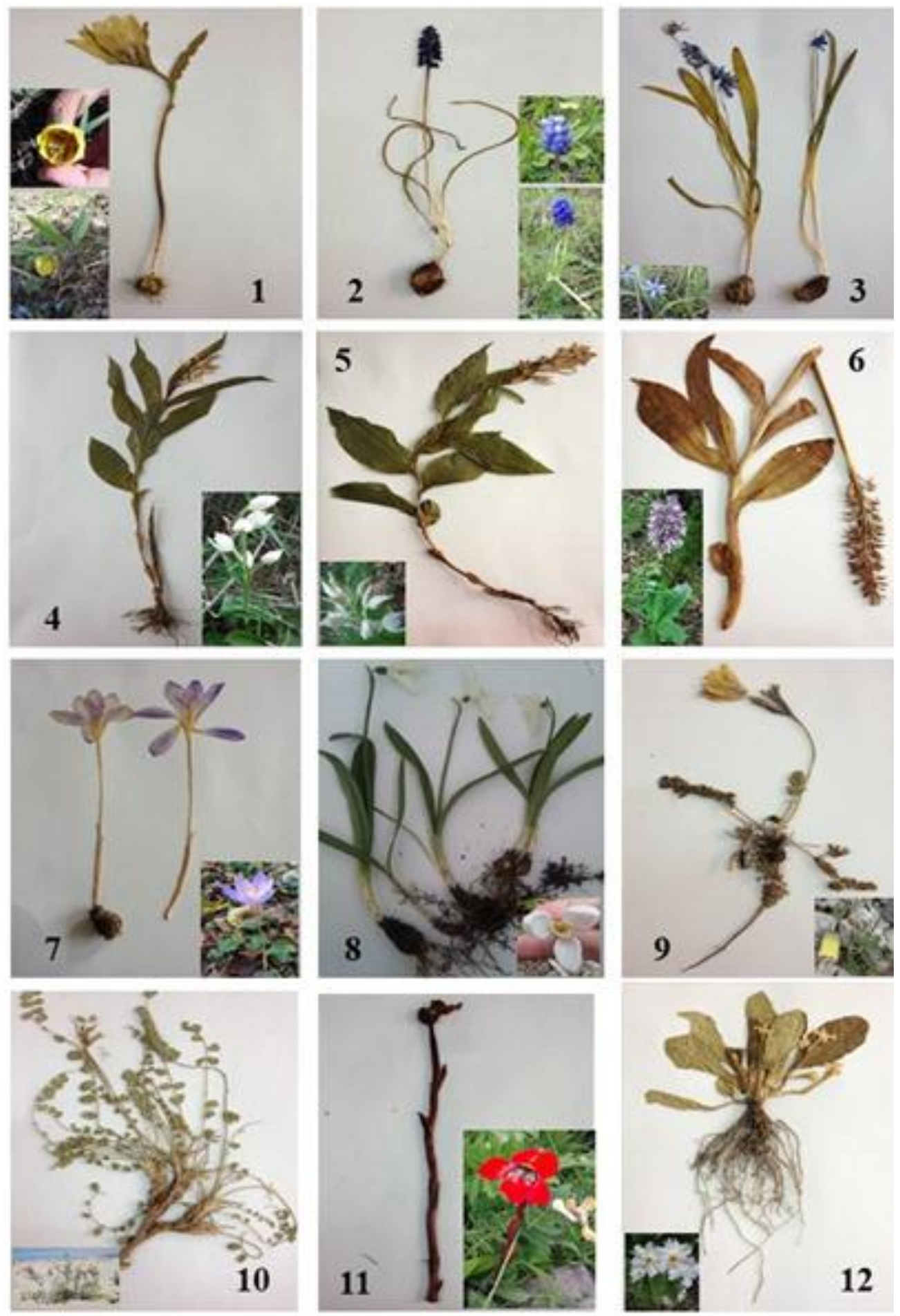

Figure. Rare grasses: 1. Fritillaria lutea Mill., 2. Muscari armeniacum Leichtlin ex Baker, 3. Scilla siberica subsp. caucasica (Miscz.) Mordak, 4. Cephalanthera damasonium (Mill.) Druce, 5. C. longifolia (L.) Fritsch, 6. Orchis purpurea Huds, 7. Crocus speciosus Bieb., 8. Galanthus alpinus Sosn., 9. Pulsatilla albana (Stev.) Bercht. \& J. Presl, 10. Asrtagalus kubensis Grossh., 11. Phelypaea coccinea (M. Bieb.) Poir., 12. Primula heterochroma Stapf. 
L. abortivum has many thick roots emerging from the short, horisontal rhizome. C. longifolia also possesses short, horizontal rhizome. Roots of the plant is highly mycorrhisal. T. coccineum is easily grown in well drained soils by seeds or rhisomes. They mainly grow in sunny dry mountainous habitats, subalpine meadows.

Few species possess roots which are modified for food and water storage, like small, flat and white bulbs: typically tunicate and consisting of few tightly packed scales in F. lutea; small, $1 \mathrm{~cm}$ ovoid to oblong surrounded with brown scales in M. armeniacum and small, 1-2 cm, ovoid to oblong, covered with dark brown or black-brown leaves in T. biebersteiniana and 1-2 cm, ovoid to oblong in $S$. siberica subsp. caucasica (Miscz.) Mordak. I. caucasica possesses brown ovoid to oblong bulbs in 2-2.5 (3.5) cm wide, which is covered with brown to dark brown tunic till the colar part. Such roots allow to grow on limestone mountain slopes in subalpine and alpine zone. Bulbs of G. alpinus are about $15 \mathrm{~mm}$ height and 8-9 (10) mm diam. with light-brown scales. The habitats of the species varies, ranging from woodlands (mixed Quercus spp., F. orientalis Lipsky) to grasslands, river banks and rocks.

Ophrys L. and Orchis L. have two subterranian tuberous roots. The tuberous orchids are not cultivated, they have low propogation rate. O. apifera has globose or ellipsoidal tubers (or corm roots) higly dependent on symbiotic relationship with mycorrhizal fungi that help the plant to extract nutrients from the soil. Tubers of $O$. sphegodes subsp. mammosa are small and globose. Greater butterfly-orchid (P. chlorantha) have two oblong-ellipsoid underground tubers with tapering apices, mainly growing in grasslanda and woodlands. Lady orchid (Orchis purpurea) prefers limestone and chalki soils. Rhizomes of $P$. albana is about $3-4 \mathrm{~cm}$ covered with dark brown scales.

Tubers of C. biflorus subsp. adamii globose to ovoid, or depressed-globose, covered with multiple thin brown tunic in the down part, and yellow cataphylls, which are accepted useful feature for taxonomic differentiation. Bieberstein's crocus is also easily cultivated species outside and in pot.

A. kubensis has well developed root system consisting of thin underground tendrilsof fine roots which better grows in the meadow environment. In study area it grows together with Astragalus onobrychis L., Vicia alpestris Stev., Polygala anatolica Boiss. \& Heldr., Ajuga pseudochia and Nonnea lutea (Desr.) DC.

Hollyhocks are the spectacular flowering plants and $A$. kusariensishas long taproot, easily grown from seeds. The plant is higly suseptible to the fungi of the genus Puccinia malvacearum Bertero ex Mont. and Golovinomyces magnicellulatus var. magnicellulatus (U. Braun) Heluta. P. algida and P. heterochroma have fibrous taproot system and shortest flowering period from the end of February till the end of April in lowlands and late flowering (May-June) in higher mountain zone.

$P h$. coccinea with rhisome type roots adapted to parasitise on the Asteraceae, such as Tanacetum and Psephellus.

Elevation diversity. Plant growth rates and development depend upon the environmental temperatures surrounding the plant, and each species has its specific minimum, maximum and optimum temperatures. Our results show that species distribution patterns along the elevation are also affected by mountain range peculiarities, slope expositions, soil types and climate warming. Most of rare species occur in low and middle mountain zone. Few species are recorded in higher elevations. Some species have been recorded in more than one altitude zone.

F. lutea grows in subalpine, alpine meadows of the study region and was found in Qusar district (Laza). T. biebersteiniana, G. alpinus and $S$. siberica subsp. caucasica grow randomly from lowland till the middle mountain zone (Quba, Qechresh). E. palustris, I. caucasica were recorded in forests from lowland till the middle mountain zone (Quba, Qaladuz). H. formosum grows from lowland till the upper mountain zone and was found in the territory of Quba (II Nugadi) and on the way from Quba to the Qusar district. L. abortivum was registered in the low mountain zone. O. apifera and $O$. sphegodes subsp. mammosa were recorded in th lowland (Quba, II Nugadi). P. chlorantha grows from lowland till the middle mountain zone. O. purpurea was found in the meadle mountain zone (Quba, Ispik; Qusar, Khuray). C. speciosus and C. biflorus subsp. adamii were registered in the middle mountain zone (Quba, Ispik).

$P h$. coccinea collected in Jek and Tulekaran villages of Quba growing together with Primula macrocalyx Binge, G. rubioides, Dracocephalum ruyschiana L., Echium russicum J.F. Gmel. and Carum carvi L., P. albana grows in the higher mountaine zone and was recorded on the rock (Qusar, the way from Anyg to Laza). A. kubensis is usualy grows up to alpine meadows (Quba, Tengealti) together with A. onobrychis, $V$. alpestris, P. anatolica, A. pseudochia and N. lutea. A. kusariensis was noted in the middle mountain zone (Qusar, Duztahir). M. armeniacum and T. coccineum 
were recorded in subalpine zone, vicinity of the villages Sudur and Laza of Qusar district. T. coccineum flowers until September. $P$. algida grows in subalpine and alpine zones.

Flowering period of plants. Most of species, such as $C$. adamii, F. lutea, $H$. formosum, L. abortivum, $P$. chlorantha, $P$. albana and $P$. algida complete their life cycle in the beginning of late spring or in early summer, in May and June. Few species such as P. heterochroma flowers from February till the end of April, I. caucasica from February till the end of May are observed in early spring, some of taxa in April and May (O. apifera, T. biebersteiniana). Some species, G. alpinus, M. szovitsianumm, $O$. sphegodes subsp. mammosa from April till July, P. coccinea flower from May till the end of July. C. speciosus flowers in October and November. Summer plants include $A$. kubensis and E. palustris that flower in June and July, A. kusariensis, T. coccineum in June and August.

\section{CONCLUSIONS}

Several species of various organisms are under protection in Azerbaijan [Red Book of Azerbaijan, 2013]. Number of plants included in the Red Book changes timely, depending on growing or reducing negative effects of environmental factors. This study represents an effort to examine rare ornamental diversity of herbs growing in Quba and Qusar districts of Azerbaijan. During centuries, natural and artificial selection pressure shaped genetic and phenotypic basis of plants growing in this area. Adapted plant species of this area currently are also strongly affected by climate change and anthropogenic pressure, which makes important to study the flora of these districts more thoroughly. The plant diversity has not been studied separately in these two districts, but earlier contributions elucidating various aspects of plants growing here have been published [Ali-zade, 2019; Caucasian flora conspectus, 2003, 2008, 2006, 2012; Flora of Azerbaijan, 1950, 1952, 1953, 1954, 1955, 1957, 1961].

Few of these species (T. biebersteiniana, $H$. formosum, L. abortivum, $O$. sphegodes subsp. mammosa as O. caucasica, O. purpurea, A. kubensis, A. kusariensis) were included to the 1 st edition, other species were published in the 2nd edition of the Red Book of Azerbaijan [1989, 2013], except $C$. longifolia, $F$. lutea and $M$. armeniacum. These three suggested as rare for the new edition.

Number of wild-growing rare ornamentals successfully was used in horticulture, landscaping of parks and gardens that make them also important. Plants with growing ability at different altitudes and various soil types are more auspicious for successful planting in new habitats. But roots of some plants do not grow by themselves alone. Roots of few orchids are highly mycorrhisal and may harbor culturable and unculturable fungi [Girlanda et al., 2006; Paduano et al., 2011]. This must be considered in planting such species.

Fritillaria L. species are commercially important in horticulture and also used in Chinese traditional medicine due to containing flavanol glycosides, alkaloids, saponins and terpenoids [Hao et al., 2013]. E. palustrisis easily grown plant in moist to wet, but well-drained soils in sunny or light shade sites. New propogation method was proposed for cultivation $O$. sphegodes subsp. mammosa [Caliskan et al., 2019]. P. albana and T. coccineum are easily cultivated.

Therefore it could be concluded that wild ornamental rare species growing in nature need more attention and conservation taking into account rapid changes in environmental factors. The future research should be focused on the evaluation of the endangered ornamental herb populations.

\section{REFERENCES}

Aghayeva P., Qarakhani P., Huseynova A., Alizade V. (2018) Wild ornamental plants of the family Asteraceae from the northeastern part of Azerbaijan. Chornomors'k. Bot. J., 14(3): 204-212. doi: 10.14255/2308-9628/18.143/1

Ali-zade V.M., Mehdiyeva N.P., Karimov V.N., Ibrahimova A.Q. (2019) Greater Caucasus, Baku: Red N Line Publ. House, 352 p.

Caliskan O., Kurt D., Cirak C. (2019) Development of new sustainable sahlep production methods using Ophrys sphegodes subsp. mammosa (Desf.) Soo ex E. Nelson. J. Agr. Sci. Tech., 21(6): 1547-1555.

Caucasian flora conspectus. Publisher St.Petersburg University. I vol., 2003, 202 p.; II vol, 2006, 466 p.; KMK Scietific Partnership, III (1) vol., 2008, 469 p.; III (2) vol., 2012, 623 р. [Конспект флоры Кавказа. Изд.-во Санкт Петербургского университета. I том, 2003, 202 с.; II том, 2006, 466 с.; Товарищество научных изданий КМК, III (1) том, 2008, 469 с.; III (2) том, 2012, 623 c.]

Corlett R.T. (2016) Plant diversity in a changing world: Status, trends, and conservation needs. Plant Diversity, 38: 10e16. http://dx.doi.org/10.1016/j. 


\section{PLANT \& FUNGAL RESEARCH}

pld.2016.01.001

Crain B.J., White J.W. (2011) Categorizing locally rare plant taxa for conservation status. Biodivers. Conserv., 20: 451-463. doi.10.1007/s10531-0109929-3

Enquist B., Feng X., Boyle B., Maitner B., Newman E.A., Jørgensen P.M., Roehrdanz P.R., Thiers B.M., Burger J.R., Corlett R.T., Couvreur T.L.P., Dauby G., Fonoghue J.C., Foden W., Lovett J.C., Marquet P.A., Merow C., Midgley G., Morueta-Holme N., Neves D.M., Oliveria-Filho A.T., Kraft N.J.B., Park D.S., Peet R.K., Pillet M., Serra-Diaz J., Sandel B., Schildhauer M., Śímova I., Violle C., Wieringa J.J., Wiser S.K., Hannah L., Svenning J.-C., CnGill B.J. et al. (2019) The commonness of rarity: Global and future distribution of rarity across land plants. Sci. $A d v .2$ (5): eaaz0414

Flora of Azerbaijan. Baku: Publishing house of Academy of Sciences of Azerb. SSR, I vol., 1950, 369 p.; II vol., 1952, 317 p.; III vol., 1952, 407 p.; IV vol., 1953, 401 p.; V vol., 1954, 578 p.; VI vol., 1955, 539 p.; VII vol., 1957, 646 p.; VIII vol., 1961, 688 р. [Флора Азербайджана. Баку: Изд-во АН Азерб. ССР. I том, 1950, 369 с.; II том, 1952, 317c.; III том, 1952, 407c.; IV том, 1953, 401c.; V том, 1954,578 с.; VI том, 1955, 539c.; VII том, 1957,646c.; VIII том., 1961, 688c.]

Girlanda M., Selosse M.A., Cafasso D., Brilli F., Delfine S., Fabbian R., Chignone S., Pinelli P., Segreto R., Loreto F., Cozzolino S., Perotto S. (2006) Inefficient photosynthesis in the Mediterranean orchid Limodorum abortivum is mirrored by specific association to ectomycorrhizal Russulaceae. Molecular Ecology., 15(2): 491-504.

Gray S.B., Brady S.M. (2016) Plant responses to climate change. Dev. Biol., 419(1): 64-77.

Hao D.C., Gu X.-J., Xiao P.-G., Peng Y. (2013) Phytochemical and biological research of Fritillaria medicine resources. Chin J Nat Medicines, 11(4): 330-344.

Heywood V. (2003) Conservation and sustainable use of wild species as sources of new ornamentals. Acta Horticulture, 598: 43-53.

Knapp S. (2011) Rarity, species richness, and the threat of extinction are plants the same as animals. PLoS Biol., 9(5): e1001067. doi:10.1371/journal. pbio. 1001067.

Mouillot D., Bellwood D.R., Baraloto C., Chave J., Galzin R., Harmelin-Vivien M., Kulbicki M., Levergne S., Lavorel S., Mouquet N., Paine C.E.T.,
Renaud J., Thuiller W. (2013) Rare species support vulnerable functions in high-diversity ecosystems. PLoS Biol., 11(5): e1001569. doi:10.1371/journal. pbio. 1001569

Paduano C., Rodda M., Ercole E., Girlanda M., Perotto S. (2011) Pectin localization in the Mediterranean orchid Limodorum abortivum reveals modulation of the plant interface in response to different mycorrhizal fungi. Mycorrhiza, 21: 97-104. doi:10.1007/s00572-010-0315-5.

Raunkiaer C. (1934) The life forms of plants and statistical plant geography. Oxford: Clarendon Press: 48-154.

Red Book of Azerbaijan SSR, 1989. 543 p. [Azərbaycan SSRİ-nin Q1rmızı Kitab1, 1989. 543 s.]

Red Book of the Republic of Azerbaijan (2013) Rare and enfangered plant and mushroom species. Second publication. Baku: Şərq-Qərb, 670p.

Serebryakov Yu.Kh. (1964) The life forms of higher plants and their studies. In: Field geobotany III: 146293. M.-L. [Серебряков Ю.Х. (1964) Жизненнык формы высших растений и их изучений. В кн.: Полевая геоботаника III: 146-293. М.-Л.: Изд. Наука]

The Plant List (2013) Version 1.1. Available at http:// www.theplantlist.org

Tutayuk V.Kh., Gadzhiev V.D., Vagabov Z.V. (1961) Wild growing ornamental plants in the mountains of the Greater Caucasus. Proceedings of the Academy of Sciences of the Azerbaijan SSR, ser.biol. and medical science, 8: 3-13. [Тутаюк В.Х., Гаджиев В.Д., Вагабов 3.В. (1961) Дикорастущие декаративные растений в горах Большого Кавказа. Известия АН Азерб.ССР, сер.биол. и медии.наук, 8: 3-13.]

Wamelink G.W.W., Goedhart P.W., Frissel J.Y. (2014) Why some plant species are rare? PLOS ONE, 9(7): e102674. doi:10.1371/journal.pone.0102674

World Flora Online (2020) WFO. Available at http:// www.worldfloraonline.org 


\section{Azərbaycanın Şimal-Şərq hissəsinin dekorativ otları}

\section{Pərvin N. Ăgayeva}

AMEA Botanika İnstitutu, Badamdar şossesi 40, Bakl, AZ1004, Azarbaycan

Məqalədə Azərbaycanın Quba və Qusar rayonlarında, Böyük Qafqazın cənub-şərq hissəsində yabanı bitən nadir bəzək ot növlərindən bəhs olunur. 2013-2019-cu illərdə ümumilikdə 500-ə yaxın nümunə toplanılmış və əsas diaqnostik morfoloji əlamətlərə əsasən 235 taksa kimi təyin edilmişdir. Onlardan 18 cinsə aid olan 21 taksa Azərbaycanın Qırmızı Kitabının ikinci nəşrinə daxil edilmiş nadir bitkilərdir. Son taksonomik və nomenklatural yeniliklər nəzərə alınaraq, bunlar beş sıra və yeddi fəsiləyə aid Alcea kusariensis, Asrtagalus kubensis, Crocus biflorus subsp. adamii, C. speciosus, Epipactis palustris, Galanthus alpinus, Himantoglossum formosum, Iris caucasica, Limodorum abortivum, Muscari armeniacum, Ophrys apifera, O. sphegodes subsp. mammosa, Orchis purpurea, Planthera chlorantha, Phelypaea coccinea, Primula algida, Primula heterochroma, Pulsatilla albana, Scilla siberica subsp. caucasica, Tanacetum coccineum vo Tulipa biebersteiniana taksonlarıdır. Növlər birdən çox hündürlük qurşağlarında qeydə alınıb. Nadir növlərin əksəriyyəti aşağı və orta dağ qurşağlarında bitir. Bir neçə növ daha yüksək qurşaqlarda müşahidə edilmişdir. Bitkilərin həyati formaları və çiçəkləmə müddəti də araşdırılmışdır. Cephalanthera damasonium, $C$. longifolia, Fritillaria lutea vo Muscari armeniacum qorunmasına ehtiyac1 olan və Azərbaycanın Q1rmızı Kitabının üçüncü nəşrinə daxil edilməsi tövsiyyə olunan yeni nadir bitkilərdir. Açar sözlor: Böyük Qafqaz, müxtəliflik, ot bitkilari, hayati formalar, Qırmızı Kitab

\section{Декоративные травы в северо-восточной части Азербайджана}

\section{Парвин Н. Агаева}

Институт Ботаники НАНА, Бадамдарское шоссе 40, Баку, AZ1004, Азербайджан

В статье рассматриваются дикие виды редких декоративных трав, произрастающих в Губинском и Гусарском районах Азербайджана, юго-восточной части Большого Кавказа. В течение 2013-2019 гг. в общей сложности было собрано около 500 образцов, которые были определены как 235 таксонов на основе основных диагностических морфологических признаков, 21 таксонов из которых относятся к 18 родам, включающим редкие виды растений, занесенные во второе издание Красную книгу Азербайджана. Учитывая последние таксономические и номенклатурные новществ, к ним относятся Alcea kusariensis, Asrtagalus kubensis, Crocus biflorus subsp. adamii, C. speciosus, Epipactis palustris, Galanthus alpinus, Himantoglossum formosum, Iris caucasica, Limodorum abortivum, Muscari armeniacum, Ophrys apifera, O. sphegodes subsp. mammosa, Orchis purpurea, Planthera chlorantha, Phelypaea coccinea, Primula algida, Primula heterochroma, Pulsatilla albana, Scilla siberica subsp. caucasica, Tanacetum coccineum и Tulipa biebersteiniana, принадлежащие к пяти отрядам семи семействам. Виды были зарегистрированы в более чем одной высотной зоне. Большинство редких видов встречается в низкой и средней горной зоне. Некоторые разновидности зарегистрированы в более высотных горных поясах. Были также исследованы формы жизни и период цветения растений. Cephalanthera damasonium, $C$. longifolia, Fritillaria lutea и Muscari armeniacum новые редкие растения, которые нуждаются в защите, и могут рассматриваться для включения в третье издание Красной книги Азербайджана.

Ключевые слова: Большой Кавказ, разнообразие, травы, жизненные формы, Красная книга 